Annals of Plant and Soil Research 23(1): 17-22(2021)

https://doi.org/10.47815/apsr.2021.10023

\title{
Sampling stage and plant part sampled to determine micronutrient sufficiency in field and horticultural crops
}

\author{
${ }^{1}$ UMESH CHANDRA GUPTA, ${ }^{2}$ PRAKASH CHANDRA SRIVASTAVA AND ${ }^{2}$ SATYA PRATAP \\ PACHAURI
}

\author{
${ }^{1}$ Agriculture and Agri-Food Canada, Crops and Livestock Research Centre, 440 University Avenue, \\ Charlottetown, PE C1A 4N6, Canada
}

Received: November, 2020; Revised accepted: January: 2021

\begin{abstract}
Plant tissue testing requires the selection of the appropriate plant part at best stage of growth when it contains higher content of nutrients. The paper discusses the appropriate stage of growth and plant part to sample for a variety of crops. Micronutrient concentrations were consistently higher in leaves than in any other part of the plant. Leaf sheath in cereals and stems in dicots contained the least amount of nutrients. It is recommended that recently matured leaves in cereals and Brassica spp., young leaves in soybeans and potatoes, and entire plant tops at the $10 \%$ bloom stage for forage legumes be sampled to determine the micronutrient nutrient status of these crops.
\end{abstract}

Keywords: Plantcomposition, plant nutrition, traces elements

\section{INTRODUCTION}

Since soil extractants have not yet been fully developed to accurately evaluate the availability of most micronutrients in soils, plant tissue testing continues to be the preferred means of determining deficiency and sufficiency levels of micronutrients in plants. It seems, therefore, desirable to sample plant parts, which contain the highest quantity of nutrients to assess the nutrient status of crops. The use of plant parts containing the higher nutrient values should facilitate better differentiation between deficiency and sufficiency levels. Plant tissue tests can aid in determining if a particular nutrient is responsible for poor crop growth. When a deficiency is determined by tissue sampling, a reduction in yield due to restricted crop growth has already occurred. The measured nutrient concentration, which is the basis of tests, varies considerably with the stage of plant development and the portion of the plant sampled.

The part of the leaf, its position in the plant, the plant's age, and the plant part are some of the factors that affect the nutrient composition of plants. Studies by Vlamis and Ulrich (1971) showed, for example, the young blades of sugar beets (Beta vulgaris L.) contained more $B$ than did the mature and old blades at lower concentrations of B. However, at higher B concentrations in solution, no such differences were found. Boron concentration in corn (Zea mays L.) leaves increased with age nearly eightfold and tassel B nearly fivefold, but $B$ in other plant parts remained low and relatively constant (Clark, 1971). Gupta and Cutcliffe (1971) reported that $B$ level in rutabaga (Brassica napobrassica, Mill) leaf tissue was greater from early samplings than it was from late samplings. Older cucumber (Cucumis sativus L.) leaves contained more $B$ than the younger leaves; and within the leaf, B accumulated more in the leaf margins (Alt and Schwarz, 1973). Generally, B in plants has a tendency to accumulate in the margin of leaves (Kohl and Oertli, 1961, Jones, 1970). Results of Miller and Smith (1977) on alfalfa (Medicago sativa L.) showed that leaves had much higher B content $\left(75-98 \mathrm{mg} \mathrm{kg}^{-1}\right)$ than the tips (47 $\mathrm{mg} \mathrm{kg}^{-}$ ${ }^{1}$ ) or the stems $\left(22-27 \mathrm{mg} \mathrm{kg}^{-1}\right)$. Testing the soil for micronutrients has become a widelyaccepted practice in recent years. However, it must be recognized that micronutrient soil tests are not as reliable as the test for soil acidity $(\mathrm{pH})$ or for phosphorus and potassium content. Therefore, this study was conducted in Prince Edward Island, Canada, and Uttarakhand Province, India to describe the best stage of plant growth and best plant part to sample to establish deficiency and sufficiency levels of micronutrients in selected field and horticultural crops. 


\section{MATERIALS AND METHODS}

These studies followed generallyaccepted recommendations as to the stage of plant growth and plant part to sample. Special care is required in taking tissue samples. Representative plant samples can be taken early in the growing season to assist in the interpretation of soil tests. Normally 25 plants should be sampled to provide a good representation of the field and ensure a sufficient quantity of the sample for complete analysis (McKenzie, 1992). Plant tissue samples should be taken from both an affected area and an adjacent area of good crops growth for comparison. The stage of growth for sampling and the plant part sampled for number of crops are described below:

Cereals:Whole plant at the boot stage when boots begin to swell (at Zadok stage 45). For small grains, sampling the entire plant above ground is recommended when the plants are 30 cm tall (Mengel, 1990).

Corn (Zea mays L.): Leaf opposite and below recently formed ear, when plants are at $50 \%$ silk stage. Mengel (1990) has recommended taking the entire plant above ground when the plants are $30 \mathrm{~cm}$ tall. Also recommendations include sampling the top ear leaf at silk initiation.

Soybeans (Glycine max L.):The unrolled leaf at the 5th node from the bottom. Other researchers recommend taking the uppermost fully-expanded trifoliate leaves (discard petiole and stem) when the plants are $30 \mathrm{~cm}$ in height to early bloom (Mengel, 1990).

Potatoes (Solanum tuberosum):The third and fourth upper most fully expanded leaves from the top of the plant.

Forages: For alfalfa (Medicago sativa L.) and red clover (Trifolium pratense L.), whole plant tops at $10 \%$ bloom and for timothy (Phleum pratense L.) at the head emerging stage.

\section{Rutabaga (Brassica napobrassica,}

Mill:Leaves when the roots begin to swell (1 to 2 $\mathrm{cm}$ in diameter): the entire leaf blade of the most recently matured leaf where lamina and petiole intercept.
Carrots (Daucus carota L.): The whole plant top, $2 \mathrm{~cm}$ above the ground level, when the roots begin to swell.

\section{Sampling the Various Plant Tissues for Micronutrient Analyses}

During the growing season, plant tissue samples of alfalfa (Medicago sativa L.), red clover (Trifolium pratense L.), broccoli (Brassica oleracea var. italica Plenck.), Brussels sprouts (Brassica oleracea var. gemmifera Zenker), cauliflower (Brassica oleracea var. Botrytis L.), and rutabagas (Brassica napobrassica, Mill) were collected from farmers' fields in Prince Edward Island, Canada. The growth stages of crops at sampling time were as close as possible to the following: alfalfa and red clover when approximately $10 \%$ of the plants were in bloom; broccoli and cauliflower when 5\% of the heads were formed, Brussels sprouts when sprouts began to form; and rutabaga when roots began to swell (about $2 \mathrm{~cm}$ in diameter). These are the generally preferred stages of growth at which these plant species are sampled to determine their nutrient status. Plant tissue samples of rice (Oryza sativa L.), wheat (Triticum aestivum L.), maize (Zea mays L.) and soybean (Glysine max L.) were also collected from the farmer's fields from Udham Singh Nagar and Almora districts of Uttarakhand province of India. The growth stages of crops were just before panicle emergence in rice and wheat, $50 \%$ tasseling in maize and flowering stage in soybean. Parts of plants and their position in the plant at time of sampling were as follows: whole vegetative tops of all crops, most recently mature leaves and stem. The $5 \mathrm{~cm}$ bottom part (stubble) of plants was not included either as a part of the whole vegetative tops or the stem.

\section{Chemical Analyses}

For nutrient analyses, a $1.2 \mathrm{~g}$ dry (at $80^{0}$. C) ground plant tissue sample was ashed at $500^{\circ}$ $\mathrm{C}$ for $3 \mathrm{~h}$. Two $\mathrm{mL}$ of $2 \mathrm{~mL} \mathrm{HCl}$ was added; and after allowing it to stand for $30 \mathrm{~min}$ the volume was made up to $2 \mathrm{~mL}$. The concentrations of $\mathrm{Zn}$, $\mathrm{Cu}, \mathrm{Mn}$ and $\mathrm{Fe}$ were determined in the filtered extract by atomic absorption spectrophotometery. Boron in the extract was analysed on an auto-analyser using the azomethine- $\mathrm{H}$ color reagent method. 
Molybdenum in the extract was analysed by the dithiol method using a spectrophotometer by the method described by Gupta (1998).

\section{RESULTS AND DISCUSSION}

The highest quantities of $\mathrm{Zn}$ and $\mathrm{Cu}$ were found in the leaves and the stem or leaf sheathes in cereals contained the least amount. (Table1). The critical Zn concentration in young mature growth was about $14 \mathrm{mg} \mathrm{kg}^{-1}$ for wheat and barley (Brennan and Bolland, 2006). Overall, broccoli contained the highest concentrations of $\mathrm{Zn}$ and $\mathrm{Cu}$ and wheat the lowest. Likewise, $\mathrm{Mn}$ and $\mathrm{Fe}$ concentrations were also highest in the leaves and lowest in the stem (Table 2). In general, the Brassicae family contained the highest amounts of $\mathrm{Mn}$ while rice grown under submerged soil conditions and soybean had the relatively higher concentration of Fe. Organic materials also have a significant effect with municipal sludge applications resulting in higher concentration of $\mathrm{Fe}, \mathrm{Zn}$ and Mn when compared to the additions of garbage or mushroom compost and chicken or cattle manure (Uyanoz et al., 2006). Bruns and Ebelhar (2006) reported that several micronutrient concentrations and contents increased as $\mathrm{N}$ fertility increased.

Table 1: Zinc and copper concentrations $\left(\mathrm{mg} \mathrm{kg}^{-1}\right)$ in plant parts $(\mathrm{pp})$ of selected crops

\begin{tabular}{|c|l|c|c|c|c|c|c|c|c|}
\hline \multirow{2}{*}{ Country } & \multirow{2}{*}{ Crop } & \multicolumn{2}{c|}{ VegetativeTops } & \multicolumn{2}{c|}{ Leaves } & \multicolumn{3}{c|}{ Stem } & \multicolumn{2}{c|}{ Crop mean } \\
\cline { 3 - 10 } & & $\mathrm{Zn}$ & $\mathrm{Cu}$ & $\mathrm{Zn}$ & $\mathrm{Cu}$ & $\mathrm{Zn}$ & $\mathrm{Cu}$ & $\mathrm{Zn}$ & $\mathrm{Cu}$ \\
\hline Canada & Alfalfa & 22 & 10.1 & 27 & 9.9 & 13 & 9.6 & 21 & 9.9 \\
& Red Clover & 31 & 13.3 & 43 & 17.8 & 16 & 9.9 & 30 & 13.7 \\
& Broccoli & 47 & 5.8 & 54 & 6.6 & 37 & 5.3 & 46 & 5.9 \\
& Brussels sprouts & 38 & 5.3 & 44 & 5.5 & 24 & 3.8 & 35 & 4.9 \\
& Cauliflower & 43 & 4.5 & 49 & 5.2 & 34 & 3.8 & 42 & 4.5 \\
& & 36 & 5.9 & 43 & 7.8 & 27 & 4.3 & 35 & 6.0 \\
& Means & 36 & 7.5 & 43 & 8.8 & 25 & 6.1 & 35 & 7.5
\end{tabular}

S.E. (mean) for $\mathrm{Zn}$ and $\mathrm{Cu}$ for $\mathrm{pp} 1.4$ and 2.8; for crops 1.5 and 0.31 and for pp $\mathrm{x}$ crops 3.3 and 6.9, respectively

\begin{tabular}{|c|c|c|c|c|c|c|c|c|c|}
\hline \multirow[t]{2}{*}{ Country } & \multirow[t]{2}{*}{ Crop } & \multicolumn{2}{|c|}{ Vegetative Tops } & \multicolumn{2}{|c|}{ Leaves } & \multicolumn{2}{|c|}{ Leaf sheath/Stem } & \multicolumn{2}{|c|}{ Crop mean } \\
\hline & & $\mathrm{Zn}$ & $\mathrm{Cu}$ & $\mathrm{Zn}$ & $\mathrm{Cu}$ & $\mathrm{Zn}$ & $\mathrm{Cu}$ & $\mathrm{Zn}$ & $\mathrm{Cu}$ \\
\hline \multirow[t]{5}{*}{ India } & Rice & 24 & 4.1 & 30 & 5.4 & 20 & 3.7 & 25 & 4.4 \\
\hline & Maize & 17 & 2.8 & 34 & 4.2 & 5 & 1.7 & 19 & 2.9 \\
\hline & Wheat & 13 & 2.2 & 22 & 4.3 & 7 & 1.4 & 14 & 2.6 \\
\hline & Soybean & 42 & 8.5 & 54 & 12.2 & 38 & 7.3 & 45 & 9.3 \\
\hline & Means & 24 & 4.4 & 35 & 6.5 & 18 & 3.5 & 25 & 4.8 \\
\hline
\end{tabular}

S.E. (mean) for $\mathrm{Zn}$ and $\mathrm{Cu}$ for pp 2.1 and 0.37 ; for crops 2.4 and 0.42 and for pp $x$ crops 4.2 and 0.73 , respectively

The higher concentrations of $\mathrm{Zn}, \mathrm{Cu}, \mathrm{Mn}$ and $\mathrm{Fe}$ found in the leaves of the investigated forage legumes and cole crops (Brassicae family) indicate that the leaves are the most metabolically active region and the site of maximum accumulation of these elements in the plants. It is also worth noting that in soybean, for example, the roots limit the translocation of $\mathrm{Cu}$ and $\mathrm{Fe}$ to the aerial parts (Silva et al.,2007). Stems of all dicotyledonous crops and leaf contained the least amounts of the micronutrient cations indicating poor accumulation ability of these cations in the stem. Among crops, the higher concentration of $\mathrm{Fe}$ in rice could be ascribed to the submerged growing conditions of rice as compared to other crops. Due to submergence, reduction of Fe (III) and Mn (IV) hydrates resulted in high build-up of soluble $\mathrm{Fe}$ and Mn in soils (Gilmour, 1977, De Datta, 1981).

Molybdenum concentrations were also highest in the leaves in cole crops, and the lowest in forages (Table 3 ). The consistently higher values of Mo found in the leaves than in the other parts of the plant are in agreement with the findings of others (Miller and Smith, 1977, Singh and Kumar, 1979). Based on the results of this study, it is recommended that wherever possible, leaves should be sampled to characterize the micronutrient status of crops. 
Table 2: Manganese and iron concentrations $\left(\mathrm{mg} \mathrm{kg}^{-1}\right)$ in plant parts $(\mathrm{pp})$ of selected crops

\begin{tabular}{|c|l|c|c|c|c|c|c|c|c|}
\hline \multirow{2}{*}{ Country } & \multirow{2}{*}{ Crop } & \multicolumn{2}{c|}{ Vegetative Tops } & \multicolumn{2}{c|}{ Leaves } & \multicolumn{2}{c|}{ Stem } & \multicolumn{2}{c|}{ Crop mean } \\
\cline { 3 - 10 } & & $\mathrm{Mn}$ & $\mathrm{Fe}$ & $\mathrm{Mn}$ & $\mathrm{Fe}$ & $\mathrm{Mn}$ & $\mathrm{Fe}$ & $\mathrm{Mn}$ & $\mathrm{Fe}$ \\
\hline Canada & Alfalfa & 33 & 66 & 50 & 87 & 10 & 40 & 31 & 64 \\
& Red Clover & 66 & 66 & 85 & 93 & 22 & 44 & 58 & 68 \\
& Broccoli & 170 & 95 & 173 & 113 & 58 & 51 & 134 & 86 \\
& Brussels sprouts & 224 & 113 & 278 & 105 & 92 & 44 & 198 & 87 \\
& Cauliflower & 128 & 91 & 169 & 117 & 57 & 55 & 118 & 88 \\
& Rutabagas & 113 & 141 & 137 & 158 & 44 & 46 & 98 & 115 \\
& Means & 122 & 95 & 149 & 112 & 47 & 46 & 106 & 84
\end{tabular}

S.E. (mean) for $\mathrm{Mn}$ and Fe for pp 18.2 and 4.4; for crops 20 and 4.4 and for pp x crops 44.5 and 10.7, respectively

\begin{tabular}{|c|c|c|c|c|c|c|c|c|c|}
\hline \multirow[b]{2}{*}{ Country } & \multirow[b]{2}{*}{ Crop } & \multicolumn{2}{|c|}{ Vegetative Tops } & \multicolumn{2}{|c|}{ Leaves } & \multicolumn{2}{|c|}{ Leaf sheath/Stem } & \multicolumn{2}{|c|}{ Crop mean } \\
\hline & & $\mathrm{Mn}$ & $\mathrm{Fe}$ & $\mathrm{Mn}$ & $\mathrm{Fe}$ & $\mathrm{Mn}$ & $\mathrm{Fe}$ & $\mathrm{Mn}$ & $\mathrm{Fe}$ \\
\hline \multirow[t]{5}{*}{ India } & Rice & 43 & 253 & 51 & 195 & 34 & 260 & 43 & 236 \\
\hline & Maize & 31 & 103 & 25 & 135 & 31 & 75 & 29 & 104 \\
\hline & Wheat & 23 & 177 & 38 & 89 & 15 & 214 & 25 & 160 \\
\hline & Soybean & 74 & 176 & 117 & 281 & 60 & 150 & 84 & 202 \\
\hline & & 43 & 177 & 57 & 175 & 35 & 175 & 45 & 176 \\
\hline
\end{tabular}

Stage of growth is very important as a stagnant growth phase may result from low temperatures between germination and the fiveleaf stage, which could cause reduced mineral availability (Leach and Hameleers, 2001). The highest $B$ concentrations were found in the leaves (Table 3). The B concentrations were lowest in the stems. The lowest B concentration was found in red clover and the highest in soybean. In a separate experiment on the effect of applied B (data not reported), similar results were observed.

Table 3: Boron and molybdenum concentrations $\left(\mathrm{mg} \mathrm{kg}^{-1}\right)$ in plant parts $(\mathrm{pp})$ of selected crops

\begin{tabular}{|c|c|c|c|c|c|c|c|c|c|}
\hline \multirow{2}{*}{ Country } & \multirow{2}{*}{ Crop } & \multicolumn{2}{|c|}{ Vegetative Tops } & \multicolumn{2}{|c|}{ Leaves } & \multicolumn{2}{|c|}{ Stem } & \multicolumn{2}{|c|}{ Crop mean } \\
\hline & & $\mathrm{B}$ & Mo & $\mathrm{B}$ & Mo & $B$ & Mo & $B$ & Mo \\
\hline Canada & Alfalfa & 24 & 0.22 & 25 & 0.28 & 14 & 0.15 & 21 & 0.22 \\
\hline & Red Clover & 21 & 0.09 & 23 & 0.12 & 16 & 0.15 & 20 & 0.12 \\
\hline & Broccoli & 36 & 3.65 & 37 & 3.76 & 21 & 1.76 & 31 & 3.06 \\
\hline & Brussels sprouts & 45 & 0.92 & 57 & 0.9 & 21 & 0.36 & 41 & 0.73 \\
\hline & Cauliflower & 30 & 1.24 & 36 & 1.65 & 19 & 0.98 & 28 & 1.29 \\
\hline & Rutabagas & 46 & 0.49 & 52 & 0.65 & 24 & 0.32 & 41 & 0.49 \\
\hline & Means & 34 & 1.1 & 38 & 1.23 & 19 & 0.62 & 30 & 0.98 \\
\hline
\end{tabular}

S.E. (mean) for B and Mo for pp 4 and 0.03 ; for crops 4 and 0.03 and for pp $x$ crops 10 and 0.07 , respectively

\begin{tabular}{|c|c|c|c|c|c|c|c|c|c|}
\hline \multirow[b]{2}{*}{ Country } & \multirow[b]{2}{*}{ Crop } & \multicolumn{2}{|c|}{ Vegetative Tops } & \multicolumn{2}{|c|}{ Leaves } & \multicolumn{2}{|c|}{ Leaf sheath/Stem } & \multicolumn{2}{|c|}{ Crop mean } \\
\hline & & B & Mo & $\mathrm{B}$ & Mo & B & Mo & $\mathrm{B}$ & Mo \\
\hline \multirow{5}{*}{ India } & Rice & 20 & 1.97 & 38 & 3.13 & 13 & 1.29 & 24 & 2.13 \\
\hline & Maize & 54 & 2.57 & 51 & 2.76 & 33 & 2.2 & 46 & 2.51 \\
\hline & Wheat & 58 & 1.98 & 77 & 2.11 & 45 & 1.78 & 60 & 1.96 \\
\hline & Soybean & 69 & 2.88 & 74 & 2.01 & 67 & 3.17 & 70 & 2.69 \\
\hline & & 50 & 2.35 & 60 & 2.50 & 39 & 2.11 & 50 & 2.32 \\
\hline
\end{tabular}

S.E. (mean) for B and Mo for pp 4 and 0.31 ; for crops 5 and 0.36 and for $p p x$ crops 8 and 0.62 , respectively

As an example, the low, marginal and sufficient amounts of various micronutrients in the boot stage tissue of cereals are reported in Table 4. Most cereal crops appear to contain the same amount of nutrients under different categories. However, $\mathrm{Cu}$ is an exception where levels are different for barley, wheat and oats. The results of Shelp (1989) showed that younger 
leaves contained less $B$ than mature leaves; it was assumed that the B supply for mature leaves was delivered principally via the xylem. The fact that B deficiency exhibits in the younger leaves and not in the older leaves can be explained by the fact that the $\mathrm{B}$ concentration was higher in the older (bottom) leaves than in the younger (upper) leaves as reported for alfalfa and red clover (Gupta and Cutcliffe, 1971) and for broccoli (Shelp, 1989). Since the B concentration in upper leaves is easily increased with B fertilization (Gupta, 1991), B deficiency is easily controlled.

Table 4: Typical micronutrient levels $\left(\mathrm{mg} \mathrm{kg}^{-1}\right)$ in cereals prior to filling (Boot Stage) *

\begin{tabular}{c|c|c|c|}
\hline Nutrient & Low & Marginal & Sufficient \\
\hline Boron & 3 & $3-5$ & 5 \\
Copper Barley & $<2.3$ & $2.3-3.7$ & 3.7 \\
Copper Wheat & $<3$ & $3-4.5$ & 4.5 \\
Copper Oats & $<1.7$ & $1.7-2.5$ & 2.5 \\
Iron & $<15$ & $15-20$ & 20 \\
Manganese & $<10$ & $10-15$ & \\
Molybdenum & $<0.01$ & $0.01-0.02$ & 0.02 \\
Zinc & $<12$ & $10-15$ & 15 \\
\hline
\end{tabular}

*Adapted after McKenzie (1992)

The plant parts which accumulate the highest concentration of nutrients during the active metabolic stage of growth are often the best choice for sampling since the higher the capacity for a plant part to accumulate a nutrient, the greater would be the differences in nutrient concentration in response to varying rates of fertilization. This has been shown to be the case, e.g., for $B$ where, in response to added B, the leaves accumulated 10 times more $B$ than did the roots (Gupta and Munro, 1969). The micronutrient concentrations in plant parts for a variety of crops have been reported by Gupta

\section{REFERENCES}

Alt, D. and Schwarz, W. (1973) Boron toxicity, boron uptake and boron distribution in young cucumber plants under the influence of various forms of nitrogen. Plant Soil 39: 277-283.

Brennan, R.F. (2006) Residual value of molybdenum for wheat production on naturally acidic soils of Western Australia.Australian Journal of Experimental Agriculture 46: 1333-1339.
(1990, 1991). Studies have shown that leaves generally contain higher concentrations of most micronutrients than, e.g., stems. The position of leaves on the plant can also have a significant, e.g., the B concentration in forage legumes was higher in the lower than in the upper leaves (Gupta, 1990).

With maturity, the Mo concentration in leaves and stems decreases (Singh and Kumar, 1979). Therefore, the growth stage of a crop must be considered an important factor when interpreting plant analytical data for Mo and possibly other micronutrients as well. It is also important to be consistent with the plant sampling technique used in the field as well as with the plant part sampled. More work however is needed on the physiology of translocation to establish the quantitative patterns of redistribution of these nutrients in various plants in response to micronutrient fertilization. It may be pointed out that the requirement for Mo by crop is very low with e.g., $0.07 \mathrm{mg} \mathrm{Mo} \mathrm{kg}^{-1}$ in the youngest emerging leaf blades being related to $90 \%$ of the maximum wheat grain yield (Brennan, 2006). The critical tissue level varies for nutrients at each growth stage, such as for $\mathrm{Zn}$ in carrots(Pettipas et al., 2008). Correlations revealed significant relationships between nutrient concentrations of critical tissues and soil largely at the active bulking stage but not at initiation of bulking in carrots.

Based on the results for a variety of crops used in this study, it may be concluded that sampling to measure micronutrient concentrations in leaves at the stage of plant growth described offers the best approach for determining sufficiency and deficiency levels of micronutrients in crops. In addition, it is important to be consistent in the sampling technique and the plant part sampled for crops in the field.

Brennan, R.F. and Bolland, M.D.A. (2006) Residual values of soil-applied zinc fertiliser for early vegetative growth of six crop species. Australian Journal of Experimental Agriculture 46: 1341-1347.

Bruns, H.A. and Ebelhar, M.W. (2006) Nutrient uptake of maize affected by nitrogen and potassium fertility in a humid subtropical environment Communications in Soil Science and Plant Analysis 37: 275-293. 
Clark, R.B. (1975) Mineral element concentrations in corn leaves by position on the plant and age. Communications in Soil Science and Plant Analysis 6: 439450.

De Datta, S.K. (1981) Principles and Practices of Rice Production. John Wiley \& Sons, Inc, New York.

Gilmour, J.T. (1977) Micronutrient status of rice plant. 1. Plant and solution concentration as a function of time. Plant Soil 46: 549557.

Gupta, U.C. (1990) Levels of micronutrient cations in different plant parts of various crop species. Communications in Soil Science and Plant Analysis 21: 17671778.

Gupta, U.C. (1991) Boron, molybdenum and selenium status in different plant parts in forage legumes and vegetable crops. Journal of Plant Nutrition14: 613-621.

Gupta, U.C. (1998) Determination of boron, molybdenum and selenium in plant tissue. In: Kalra YP (ed) Handbook of Reference Methods for Plant Analysis, CRC Press, Boca Raton, pp 171-182.

Gupta, U.C. and Cutcliffe, J.A. (1971) Determination of optimum levels of boron in rutabaga leaf tissue and soil. Soil Science 111: 382-385.

Gupta, U.C. and Munro DC (1969) The boron content of tissues and roots of rutabagas and of soil as associated with brownheart. Soil Sci Society of America Proceedings 33: 424-426.

Jones, Jr. J.B. (1970) Distribution of fifteen elements in corn leaves. Communications in Soil Science and Plant Analysis1: 27-33.

Kohl, Jr. H.C. and Oertli, J.J. (1961) Distribution of boron in leaves. Plant Physiology 36: 420424.

Leach, K.A. and Hameleers, A. (2001) The effects of a foliar spray containing phosphorus and zinc on the development, composition and yield of forage maize. Grass and Forage Science 56: 311-315.

McKenzie, R.S. (1992) Micronutrient requirements of crops. Alberta Agriculture, Edmonton, Alberta, pp 6.

Mengel, D.B. (1990) Role of micronutrients in efficient crop production. Agronomy Guide, Purdue University, Cooperative Extension Service, West Lafayette, Indiana.

Miller, D.A. and Smith, R.K. (1977) Influence of boron on other chemical elements in alfalfa. Communications in Soil Science and Plant Analysis 8: 465-478.

Pettipas, F.C., Lada, R.R., Caldwell, C.D. and Warman, P. (2008) Critical tissue identification and soil-plant nutrient relationships in dicer carrot Communications in Soil Science and Plant Analysis 39: 763-788.

Shelp, B.J. (1989) Mineral nutrient distribution: significance in the nutrition of vegetable crops. Highlights of Agricultural Research in Ontario12: 21-24.

Silva, M.L. De, Vitti, G.C. and Trevizam, A.R. (2007) Concentration of heavy metals in grain of plants cultivated in soil with different contamination levels. Pesquisa Agropecuaria Brasileira 42: 527-535.

Singh, M. and Kumar, V. (1979) The effect of forms of selenium on the accumulation of selenium, sulfur, and forms of nitrogen and phosphorus in forage cowpeas (Vignas sinensis). Soil Science127: 264269.

Uyanoz, R., Cetin, U. and Karaarslan, E. (2006) Effect of organic materials on yields and nutrient accumulation of wheat.Journal of Plant Nutrition 29: 959-974.

Vlamis, J. and Ulrich, A. (1971) Boron nutrition in the growth and sugar content of sugarbeets. Journal of the American Society of Sugarbeet Technologists 16: 428-439. 